\title{
Transcending the Traditional: Fashion as Performance
}

\author{
Jennifer Richards
}

\begin{abstract}
From Fashion's inception, there has been an intrinsic link between clothing, performance and the body. This dialogue has been evident throughout the last century and into the present. This paper will examine contemporary examples of the pose through fashion shows, fashion displays and fashion performances. It will discuss the work of Daphne Guinness and Viktor and Rolf, and how their work seeks to reflect the historical associations of the pose but updates this mode within the $21^{\text {st }}$ century fashion climate. It will also consider Olivier Saillard's work which examines the use of the pose with the contemporary fashion industry. His trilogy of work with the actress Tilda Swinton examines the history of couture, its process and creation, and the viewer's relationship within the body and garment. These examples seek to break the barriers of the traditional modes of the pose within the fashion context. They ask questions as to our own relationship with clothing and the body, imbuing meaning and symbolism into their work. This paper will argue that these new modes help to raise the profile of the pose as performance, raising their status to work in part as a spiritual medium, evoking emotional responses in our own readings of the work.
\end{abstract}

\section{Key Words}

Performance, pose, body, meaning, symbolism

\section{Introduction}

In recent years, there has been an increasing number of collaborations between the Visual Arts and the world of Fashion. Major fashion houses have sought out collaborations with performance-based artists such as Marina Abromovich (co-art directing Givenchy's shows) Yeezy \& Vanessa Beecroft. Most recently Clare Waight Keller included hip hop ballet dancers within her debut for Givenchy S/S18. These particular catwalk shows have become art installation pieces, more akin to the ideas behind the rise of Conceptual Art or the Fluxus movement (think shades of Joseph Kosuth and his infamous coyote). These parallels although interesting and engaging, are not wholly new. Andy Warhol famously collaborated with many artists and designers in his Factory studio in the 1960s. So why this re-emergence of interest in performance and Fashion?

Steven Sebring's Study of Pose - A 1000 poses of Coco Rocha has demonstrated that there is growing interest in the dialogue between the traditional uses of the pose in fashion from the Salon through to the more contemporary uses of the pose in fashion photography, film and performance. Historically in the traditional use of the fashion pose, the Parisian Salon was the location for the parade of fashion where clients and buyers could view items displayed by a model in the precursor to today's modern catwalk shows. The growing interest in performance demonstrates that the use of movement or stillness can be seen as an important vessel to begin a dialogue around the importance of the pose within a $21^{\text {st }}$ century climate.

There are a wide range of creative individuals within Fashion that are exploring ideas surrounding the use of the pose. Daphne Guinness creates performance pieces inspired by her friends and her love of fashion. The designers Viktor and Rolf have evolved the traditional use of the catwalk show into a new space in which Art and Fashion collide. Olivier Saillard's curatorial and performative work, particularly with the actress Tilda Swinton, seeks to create a dialogue between the traditional and more contemporary face of fashion. All three collaborators works are an attempt to try and elevate the status of the pose within their work, imbuing each work with a sense of spirituality. They are all transcending the traditional boundaries of the pose and use of movement in fashion into something more esoteric and otherworldly.

The British artist and socialite Daphne Guinness created her piece Remembrance of Things Past in 2011. Guinness referred to the performance as a 'poetic gesture'1 to both Alexander McQueen and Isabella Blow. Blow was both daring and provocative and established a legacy within the Fashion industry. This work was an attempt to represent Blow's personality and joie de vivre. An unusual location was selected, this being Barney's store front window. It became a location to both curate and showcase work from Alexander McQueen's and Isabella

\footnotetext{
${ }^{1}$ Louise Carpenter, 'Daphne Guinness on her friend Alexander McQueen's tragic death' The Telegraph 30 April 2016 viewed 8 April 2016. http://www.telegraph.co.uk/fashion/people/daphne-guinness-on-her-friendalexander-mcqueens-tragic-death-i/
} 
Blow's collections. At this time, Guinness was custodian for Blow's collection, and it the piece was performed to coincide with the opening night of Alexander McQueen's Savage Beauty exhibition being held at the Met.

Walking into the window in a McQueen jumpsuit, Guinness' head is covered. She poses outstretched onto a table, then undresses behind a screen, (the viewer can see her gyrating in silhouette). She then reappears in front of the crowd in one of McQueen's signature gowns. She removes the scarf from her head, reveals her face then exits. This performance totals eight minutes in length.

This work is a love letter to her two friends. It is an attempt to demonstrate her ability to create a tribute to both Blow and McQueen in her unique and highly imaginative way. The element of transformation is a key part of the performance, and resonates with the viewer. McQueen used many different tropes and transformations throughout his collections, and had a particularly fondness for the macabre and the gothic. This sense of drama and melancholy is present when viewing the work. The audience can sense this emotional connection between the three collaborators through Guinness' presence, and by omission, the absence of both Blow and McQueen. Guinness herself states that the work seeks to 'transform the wearer and in turn, it transforms the piece - it locks'2.

Daphne Guinness went on that year to collaborate on another performance with jeweller Shaun Leane. This work titled Contra Mundum (translated as Against the World), manifested itself in the form of an armoured glove. Guinness suggested this piece represented a means of armouring the self against the outside world. The glove had the aesthetics of an evening glove and was made from $18 \mathrm{ct}$ white gold but visually sought to replicate lace or silk, due to the intricate jewel work by Leane. Articulated fingers and detailed birds were worked into the piece. This piece became symbolic of their collaboration, the piece therefore transformed into an objet d'art. It was both a reflection of their friendship and homage to McQueen who contributed to the initial idea.

The work was showcased with Guinness lying on a baise, surrounded by candles, shrouded and veiled wearing the glove. Her arm was the only part of her body that was on show and exposed to the viewer. Members of the party could then step forward to gaze upon her, revering her as if she were a knight lying in state after a great battle. Like a medieval warrior, the performance allows Guinness to become a modern-day Joan of Arc. Dressed in the bespoke glove and shrouded in white silk tulle, her lie-in state as her gloved hand lay over the tulle and rested on her upper-body, symbolising the concept of the objet d'art.

This work like Remembrance of Things Past was highly theatrical. An installation piece, reminiscent of the works of the Fluxus era, it sought to evoke both the past and the future simultaneously. It engaged with the public actively, not just in a passive manner as an audience would traditionally view a performance work. Here individual members of the party were invited to step forward and view Guinness in her lie-in state. Each individual had their own unique experience of the work, and they became part of both Guinness' process and outcome.

Avant-garde designers Viktor and Rolf chose to revolutionise the catwalk show by removing it completely when showing their collection in 1999. For their Russian Doll collection, they used just one model to display the collection. Model Maggie Rizer was placed onto a revolving turntable, a barrage of clothes layered onto her body in excess of 70 kilogrammes.

The audience became active participants in the performance. Like Guinness' works, they became an intrinsic part of this new spectacle. They were audible gasps of adoration and amazement whilst the designers performed the act of adding more and more garments to their model. These items began with lighter fabrics such as slips and shirts to a final over-sized and intricately patterned coat. The overall effect of this mass of clothing was in the finale, the creation of a real-life Russian doll. Critic Andre Leon Talley called the collection, 'The Viagra of couture week'3

This example of Viktor and Rolf's work pushes the boundaries of fashion within this period of time, and questions how we as the audience view fashion and fashion shows. Viktor and Rolf purposefully mock the traditional constructs of the fashion show in order to create their own vision of what contemporary fashion should be. This is a major part of their design philosophy, and they have continued to do this in subsequent works. For example, their A/W 2015 fashion show they took on the role of performance artists. They removed the items from each of the models once they had walked the catwalk then hung them on the white wall which enclosed the catwalk. Here the garments became art objects to be revered by the establishment. The final look was reminiscent of a Dutch Master Painting, although somewhat deconstructed in the guise of Conceptual Art. Both these works demonstrate what Viktor and Rolf's work is all about. The ideas and concepts are paramount to the two designers as they continue to push the boundaries of what is expected.

Like Viktor and Rolf before him, Olivier Saillard has continued this dialogue with the pose in his own performance pieces. As a high-profile fashion curator and fashion historian, he has the opportunity and platform to explore his ideas further. Throughout his work, he has sought to create a discourse transforming our preconceived notions associated with the pose in fashion and the fashion industry. An example of this is his work Models Never Talk (2014). This work seeks to uncover the relationship between the model and the designer.

\footnotetext{
${ }^{2}$ Contra Mundum, dir. Brennan Stasiewicz, London, UK, 2011. DVD

${ }^{3}$ Andre Leon Talley, 'Fall 1999 Couture - Viktor and Rolf' Vogue October 1999 viewed 15 April 2016.
} 
Traditionally, a model can be a muse, helping to develop how a designer may envisage that season's fashion from the conception of an idea through to the final collection. Saillard uses this particular performance to demonstrate the difference when models enter the catwalk. Here the models fall silent and the dialogue is lost. They are viewed only as a prop for the clothing to be displayed.

Further to this, his subsequent trilogy of work with the actress Tilda Swinton examines the history of couture, its process and creation, and the viewer's relationship within the body and garment. These three works also attempt to examine our deep-seated desires and responses to clothes.

The first collaboration with Swinton was The Impossible Wardrobe (2012). Here Saillard and Swinton combine to give the viewer a glimpse into a museum collection, he as caretaker and she as model. There are around 54 items displayed for the viewer including garments and accessories by designers such as Lanvin and Schiaperelli. Napolean Bonaparte's jacket also makes an appearance. Swinton takes on the role as model and walks along a catwalk which ends with a full-length mirror. Here she uses her body as a gesture, imbuing the clothing with expression or movement. She interacts with each garment or accessory differently, as if she can feel their emotional needs and desires. There is a sense of tension in the piece, as these items have been housed in museum collections for years, static and untouched, preserved for the public to view. Swinton carefully constructs the narrative of each item, demonstrating the close connection we have with beauty, craft and the previous wearer of these exquisite pieces. Each piece is also described above Swinton's head as she collects it from Saillard. This again emphasises the connection we make with the knowledge of an item. Our aesthetic desire to see items lost amongst the centuries is revived. Some items are lovingly caressed, others held aloft as art objects. There is a tension between our needs as a viewer to be visually enthralled, but also the experience of these items is somewhat tinged with a sense of loss. The items become a type of a memento mori; they become ghosts of the past.

Their second collaboration was for the work titled Eternity Dress (2014). This performance follows the design process of creating a dress from initial sketch to finished garment. Saillard examines the historical use of the haute couture dress making process. He examines this mode through the fine art process, drawing comparisons with garment making and the creation of artworks. Swinton works as muse throughout the process and inspiration, posing throughout the garment making process. Swinton is measured; the pattern is drawn and cut as Saillard tests out a range of sleeves, collars and details for the dress.

Saillard adds additional pockets, and then Swinton seeks to remove them as his back is turned. Swinton also removes or dismisses certain items as the process evolves. Here she interacts with the design process, which is highly unusual within traditional haute couture dressmaking techniques. Traditionally, the model is static, they are the hanger. There is no need to speak with them or an opinion to be formed of the designers' vision. The next stage demonstrates the selection of the chosen cloth, which is then draped across Swinton. Swinton then sews herself into the canvas toile. When the dress is complete, she models this 1930s-inspired gown as if it were an item by Balenciaga, posing in the iconic shapes and gestures of the designer. Within her performance of the garment she also makes nods to YSL's Le Smoking, with her hand in her pocket and then removes her shoes in homage to Rei Kawakubo.

The work can be seen as a statement alluding to the contemporary fashion system, Saillard seeking to bring back the traditional haute couture methods in opposition to the desire for fast fashion items created at incredible speed due to increasing consumer demand. This works asks us to look at the craftsmanship and artistry that goes in to the creation of a bespoke item. Saillard and Swinton seek to emphasise each in individual stage of the process, the meticulous accuracy and painstaking development of each stage. We as the audience are asked to re-think our preconceived notions of the garment making process.

Their final collaboration was for the work Cloakroom Vestiaire (2015). This work embraces the interactive qualities of the performance piece. Members of the public are asked to deposit items of clothing to the 'coat check lady' in this case, Swinton. Swinton carefully selects an item to interact with. As with Saillard's previous works, the emphasis is on the interaction of Swinton with the clothing. With some items she speaks to them, with others she carefully scrutinises their details. She also places items in pockets of garments, kissing tissue paper with her lipstick and placing it into a jacket pocket. She also includes flowers, poems and written fragments, adding her own personality or experience into each item, changing it forever after her time with the item. Swinton forcibly imposes herself on these items, changing them forever within a few minutes of interaction.

This works asks us to question our relationship with the clothes we wear, the clothes we love, and the ones with memories of significant events. It is a way to examine ourselves, what we as individuals project out into the world, our innermost desires expressed through our clothes. This works adds another dimension to the experience within this trilogy of work as it involves the audience more directly. They are less passive observers; they become an important part of the performance. Their personal items become both the process and outcome of the work. Saillard states that the work is about 'how one day our own clothing will be granted meaning in a museum context, purely because it is ours ${ }^{4}$.

\footnotetext{
${ }^{4}$ Olivier Saillard, ‘Cloakroom Vestiarie’ Interview Magazine Autumn/Winter 2015.
} 
Examining the trilogy of work Saillard has created, Eternity Dress and The Impossible Wardrobe are more passive, and they are more akin to the traditional fashion show. In both works, items are displayed for the audiences' pleasure, they are examined or showcased as you would see them in a Salon. Swinton uses traditional poses to display the items, gestures which are associated with the high fashion poses. Cloakroom Vestiaire breaks the fourth wall of theatre, affecting the audience with the performance, rather than as a passive observation on aesthetics such as the garments colour or use of craft.

In conclusion, Daphne Guinness, Viktor and Rolf and Olivier Saillard seek to investigate how clothes are inhabited. They attempt to look at ways of reinventing clothing with our experience of viewing items on models. They try to change the perception of the fashion show from a passive spectacle to a personal and more individual experience. It can be argued that the fashion industry itself is built on facade, emphasising the aesthetic beauty or visual as of paramount importance. Therefore, these works force us as individuals to begin to look internally at ourselves and not rely on our external qualities. They attempt to celebrate the individuality of an item, the person, or the designer. These examples seek to break the barriers of the traditional modes of the pose within the fashion context. They ask questions as to our own relationship with clothing and the body, imbuing meaning and symbolism into their work. They all continue to raise the importance of performance based works to evoke emotional responses in our own readings of the work.

Saillard's work is a reflection of this continuing dialogue. His work has evolved throughout the trilogy creating a new space in which to discuss fashion and performance. Throughout the journey of the three performances, Saillard has systematically moved away from the more tradition notions of the museum context and fashion history, into something more contemporary. This new way of seeing is more akin to the performance artists, breathing life into the fashion system, creating new and exciting possibilities and sources of inspiration for the next generation of visual artists. This move highlights new possibilities for collaboration and interdisciplinary modes of working for a wide range of practitioners and disciplines. Long may it continue. 


\section{Bibliography}

Brand, Jan. Fashion and Imagination: About Clothes and Art Netherlands : ArtsEZ Press, 2010.

Carpenter, Louise. 'Daphne Guinness on her friend Alexander McQueen's tragic death'. The Telegraph, 30 April 2016.

Contra Mundum. Directed by Brennan Stasiewicz. London, UK:2011.DVD

Miller, Sanda. 'Fashion as Art: Is Fashion Art?' Fashion Theory Journal of Costume and Dress Journal (2007) 25-40.

Saillard, Olivier. Cloakroom Vestiarie, Eternity Dress, The Impossible Wardrobe London: Rizzoli International, 2015.

Saillard, Olivier. 'Cloakroom Vestiarie'. Interview Magazine, A/W 2015.

Sebring, Steven. Study of the Pose - 1,000 Poses by Coco Rocha London: Harpers Collins, 2014.

Talley, Andre Leon. 'Fall 1999 Couture- Viktor \& Rolf'. Vogue October 1999. 